\title{
Simultaneous Method Development, Validation and Stress Studies of Darunavir and Ritonavir in Bulk and Combined Dosage Form Using UV Spectroscopy
}

\author{
Dr. K. Bhavyasri ${ }^{1 *}$, M. Sreshta ${ }^{2}$, Dr. M. Sumakanth ${ }^{3}$
}

\footnotetext{
${ }^{1}$ Associative Professor, Department of Pharmaceutical Analysis, RBVRR Women's College of Pharmacy, Barkatpura, Hyderabad, India

${ }^{2}$ Research Student, Department of Pharmaceutical Analysis, RBVRR Women's College of Pharmacy, Barkatpura, Hyderabad, India

${ }^{3}$ Professor and Principal RBVRR Women's College of Pharmacy, Barkatpura, Hyderabad, India
}

DOI: $\underline{10.36347 / \text { sajp.2020.v09i08.003 }}$

| Received: 12.08.2020 | Accepted: 20.08.2020 | Published: 30.08.2020

*Corresponding author: Dr. K. Bhavyasri

Abstract

Original Research Article

A simple, specific, accurate and precise UV Spectrophotometric method has been developed for the simultaneous estimation of Darunavir and Ritonavir in pharmaceutical dosage form. The absorption maxima of the Darunavir and Ritonavir were found to be $267 \mathrm{~nm}$ by using methanol and 240nm using methanol: water as solvent and isosbestic point found at $254 \mathrm{~nm}$. This method obeys beers law in the employed concentration range of $2-18 \mu \mathrm{g} / \mathrm{ml}$ and 5 $100 \mu \mathrm{g} / \mathrm{ml}$ for Darunavir and Ritonavir respectively. Different analytical validation parameters such as linearity, precision, accuracy, limit of detection (LOD) and limit of quantification (LOQ) were determined according to ICH guidelines. The accuracy of the method was confirmed by recovery studies of tablet dosage form and was found to be $100 \%$ and $99 \%$ for Darunavir and Ritonavir respectively. The LOD of Darunavir and Ritonavir was found to be $0.043 \mu \mathrm{g} / \mathrm{ml}$ and $0.024 \mu \mathrm{g} / \mathrm{ml}$ respectively and LOQ of Darunavir and Ritonavir was found to be $0.132 \mu \mathrm{g} / \mathrm{ml}$ and $00.078 \mu \mathrm{g} / \mathrm{ml}$ respectively. The developed method was free from interferences due to excipients present in formulation and it can be used for routine quality control analysis.

Keywords: Absorption maxima, analytical, validation parameters, Darunavir, Ritonavir, ICH guidelines. Copyright @ 2020: This is an open-access article distributed under the terms of the Creative Commons Attribution license which permits unrestricted use, distribution, and reproduction in any medium for non-commercial use (NonCommercial, or CC-BY-NC) provided the original author and source are credited.

\section{INTRODUCTION}

Darunavir ethanolate (DRV) is an antiviral drug used in the treatment of human immunodeficiency virus (HIV) protease. It was approved in the year 2006 by the Food and Drug Administration(FDA), it isschemically[(1S,2R)-3-[[(4-aminophenyl)sulfonyl](2methylpropyl)amino]-2-hydroxy-1-(phenylmethyl) propyl]- carbamic acid $(3 R, 3 \mathrm{a} S, 6 \mathrm{a} R)$ hexahydrofuro [2,3-b] furan-3-yl ester monoethanolate.

DRV is a second-generation protease inhibitor, it will selectively inhibit the cleavage of HIV-1 encoded Gag- Pol polyproteins in the infected cells, and thereby it prevents the formation of mature virus cells [1-6].

DRV is used with Ritonavir and other medications to treat HIV. It works by slowing the spread of HIV in the body. Ritonavir is an antiretroviral drug from the protease inhibitor class it is used to treat HIV infection and AIDS. The chemical it is $(5 \mathrm{~S}, 8 \mathrm{~S}$, 10S,11S)-10-hydroxy-2-methyl-5-(1-methylethyl)-1-[2(1-methylethyl)-4thiazolyl]-3,6-dioxo-8,11- bis(phenylmethyl)-2,4,7,12-etraazatridecan-13-oic acid 5-thiazolyl methyl ester. Ritonavir is frequently prescribed with Highly Active Anti-Retroviral Therapy, not for its antiretroviral action, but it will inhibit the same host enzyme that metabolizes other protease inhibitors. This leads to increases in plasma concentrations of these latter drugs, allowing the clinician to lower their dose and frequency and improving their clinical efficacy.

From the literature survey it was found that the analytical methods have been reported for the determination of the darunavir in spectrophotometric method and individually in human plasma by liquid chromatography/tandem mass spectrometry, and from the literature survey it was found that Ritonavir estimated by analytical methods such as spectrophotometric methods, reversed phase high performance liquid chromatographic (RP-HPLC) method7-13, LC-MS14 and HPTLC15 method. Apart from the above, no other methods are also present such as zero and first order derivative spectrophotometric 
method was reported for the quantitative determination of (RIT)in pharmaceutical dosage forms. The present work describes the simple precise, accurate and specific for the simultaneous determination of drugs by UV spectrophotometric method [7-12].

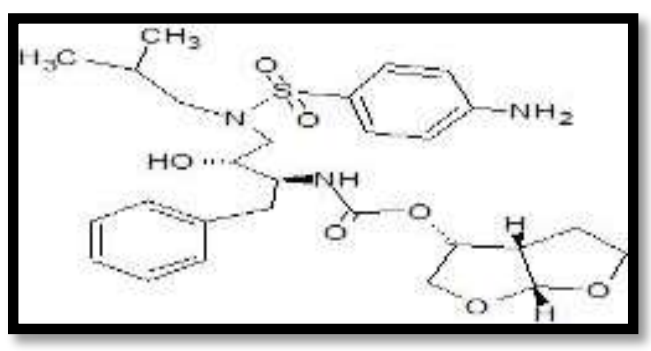

Fig-1: Structure of Darunavir

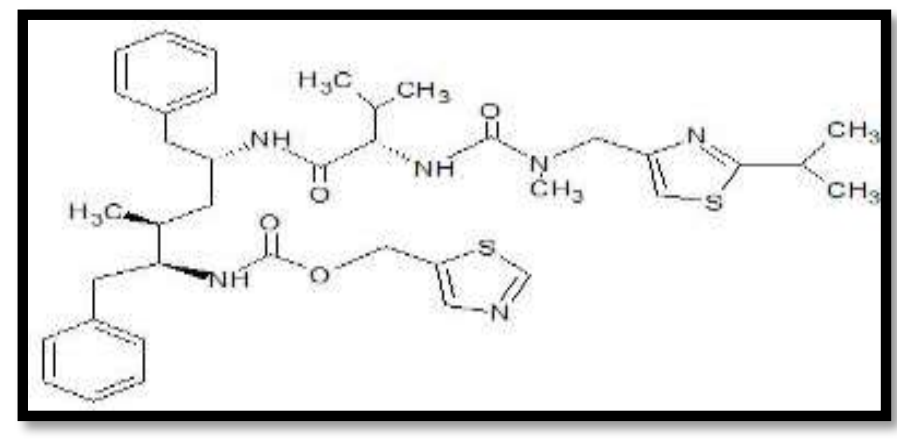

Fig-2: Structure of Ritonavir

\section{Introduction to UV spectroscopy}

UV-Visible Spectroscopy is type of absorption Spectroscopy in which light of ultra-violet region (200$400 \mathrm{~nm}$ ) is absorbed by the molecule.

Principle: UV-Visible Spectroscopy obeys the beer-lamberts law, which states that: when a beam of monochromatic light is passed through a solution of an absorbing substance, the rate of decrease of intensity of radiation with thickness of the absorbing solution is proportional to the incident radiation as well as the concentration of the solution.

\section{This law is expressed as}

$\mathrm{A}=\log \left(\mathrm{I}_{0} / \mathrm{I}\right)=\varepsilon \mathrm{cl}$

$\mathrm{A}=$ Absorbance.

$\mathrm{I}_{0}=$ Intensity of light upon a sample cell.

$\mathrm{I}=$ Intensity of light departing the sample cell.

$\mathrm{C}=$ Concentration of the solute.

$\mathrm{L}=$ Length of the sample cell and

E=Molar absorptivity [13-18].

\section{MATERIALS AND METHODS \\ Chemical and reagents}

Darunavir and Ritonavir were obtained as a gift sample from Pharmaceuticals, Hyderabad, telangana, Methanol and other chemicals were analytical grade from Rankem chemicals limited.

\section{Instrumentation}

Spectroscopic analysis was carried out using Elico SL-210UV/Vis-Double beam spectrophotometer with Spectral treaties software. Spectrophotometer with spectral width $2 \mathrm{~nm}$, wavelength accuracy of $0.5 \mathrm{~nm}$ and a pair of $10 \mathrm{mmmatching}$ quartz cells was used to measure absorbance of the resulting solutions.

\section{Selection of common solvent}

After assessing the solubility of drugs in different solvents Methanol has been selected as common solvent for developing spectral characteristics.

\section{Selection of wavelength}

Weigh accurately about $10 \mathrm{mg}$ of Darunavir in a $10 \mathrm{ml}$ volumetric flask and add methanol until the substance completely dissolves and make the volume up to $10 \mathrm{ml}$ with methanol in $10 \mathrm{ml}$ volumetric flask to obtain the $1000 \mu \mathrm{g} / \mathrm{ml}$ of the component and $10 \mathrm{mg}$ of Ritonavir in a $10 \mathrm{ml}$ volumetric flask and add methanol: water (6:4) and make the volume up to $10 \mathrm{ml}$ with methanol: water in $10 \mathrm{ml}$ volumetric flask to obtain the $1000 \mu \mathrm{g} / \mathrm{ml}$ of the Ritonavir and these both the drugs are further diluted to get $10 \mu \mathrm{g} / \mathrm{ml}$ of Darunavir (standard stock solution A) and $10 \mu \mathrm{g} / \mathrm{ml}$ of Ritonavir (standard stock solution B) in a separate volumetric flask. These dilutions were scanned from 200-400 nm respectively. Wavelengthsof darunavir $267 \mathrm{~nm}$ and 240nm for the Ritonavir respectively and according to the label claim 1; 8 dilutions of DRV and RIT were scanned between $200-400 \mathrm{~nm}$ isosbestic points found at $254 \mathrm{~nm}$. 


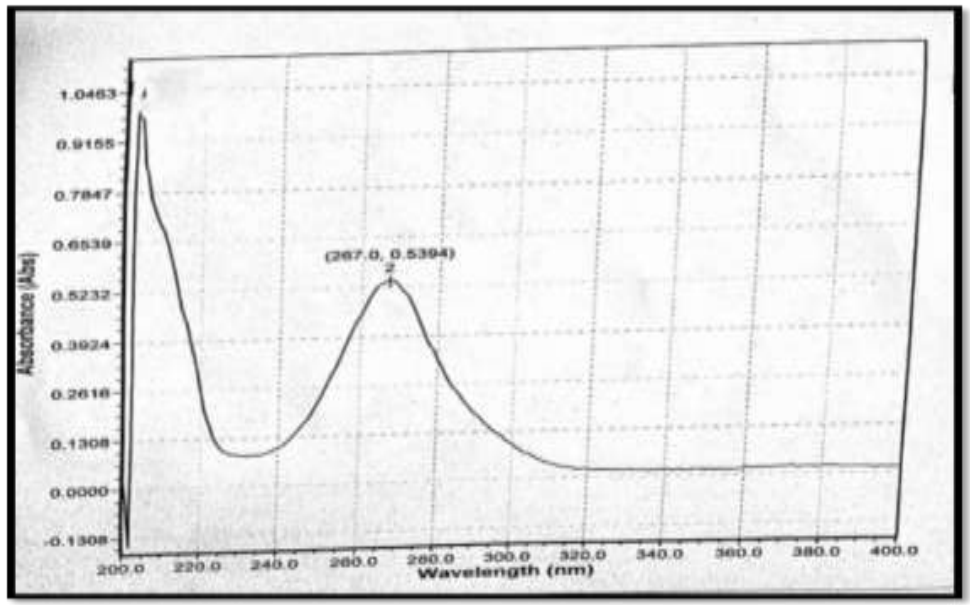

Fig-3: Spectra of Darunavir

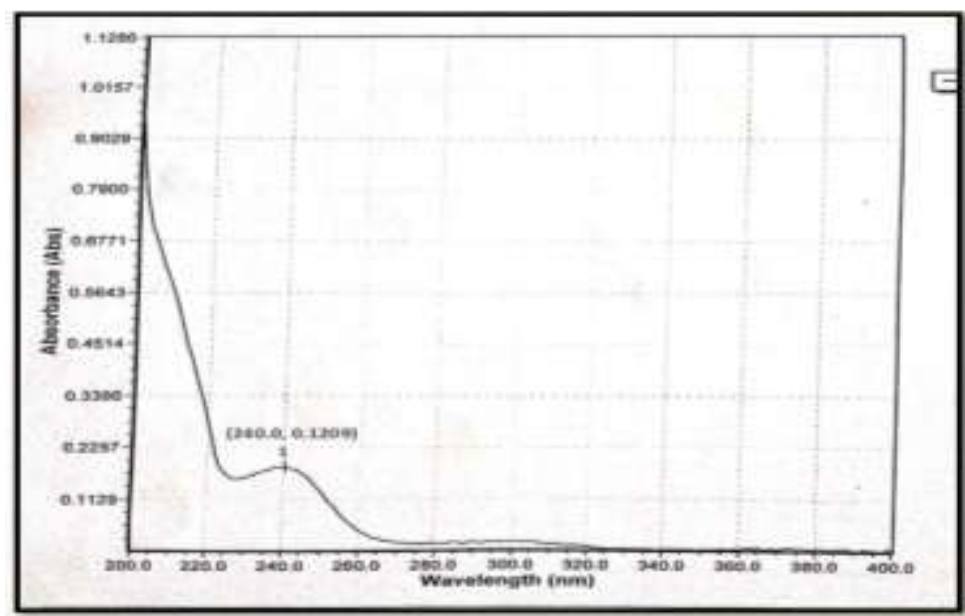

Fig 4: Spectra of Ritonavir

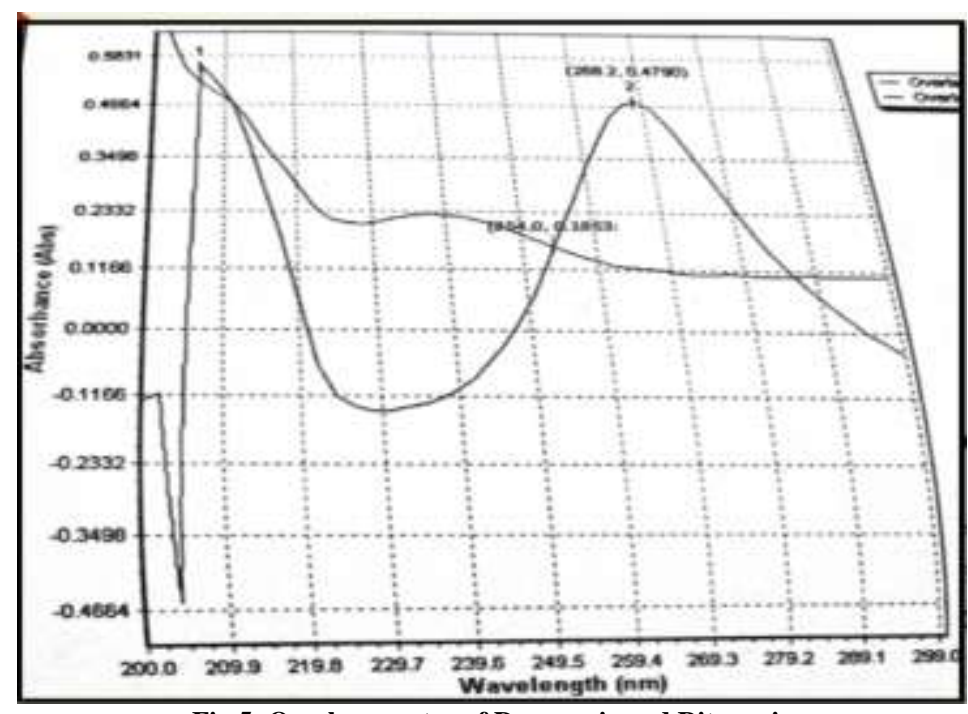

Fig 5: Overlay spectra of Darunavir and Ritonavir

\section{Preparation of standard stock solution}

$10 \mathrm{mg}$ of DRV and RIT were separately weighed in $10 \mathrm{ml}$ volumetric flask and dissolve with methanol for DRV and methanol; water $(6 ; 4)$ for RIT to get concentration of $1000 \mathrm{ppm}$ from this 1 in $10 \mathrm{ml}$ was prepared to get the concentration of $100 \mathrm{ppm}$.

\section{Validation parameters}

Validation: It is defined as establishing documented evidence which provides a high degree of assurance that a specific process will produce a product meeting its predetermined specifications and quality characteristics. 


\section{Linearity}

various standard solutions of Darunavir were prepared by pipetting 0.2 to $2 \mathrm{ml}$ of stock solutions ( 100 $\mu \mathrm{g} / \mathrm{ml}$ ) of DAR in $10 \mathrm{ml}$ of volumetric flasks and volume made up to the mark by methanol to obtain the concentrations of $2-20 \mu \mathrm{g} / \mathrm{ml}$.then,thestandard solutions of Ritonavir were prepared by pipetting $0.5-10 \mathrm{ml}$ from(stock solutions $100 \mu \mathrm{g} / \mathrm{ml}$ ) of RIT in $10 \mathrm{ml}$ of volumetric flasks and the volumetric flasks and volume was made up to the mark by methanol: water(6:4) to obtain the final concentrations of $5-100 \mu \mathrm{g} / \mathrm{ml}$.

\section{Precision}

Darunavir (10ppm) using methanol and RTV (50ppm) using methanol: water (6:4) as diluents the standard solutions were prepared separately and precision study was performed This procedure is repeated 6 times and absorbance of all were measured at $267 \mathrm{nmand} 240 \mathrm{~nm}$ for DAR and RTV, and its \%RSD was calculated by using the formula: $\%$ RSD $=$ (standard deviation of the measurement / mean value of measurement)*100 repeated for 6 times and its \%RSD was calculated.

\section{Accuracy}

The Accuracy was determined by spiking the sample matrix of interest with a known concentration of analyte, the recovery studies were carried at three different levels $(50,100$ and $150 \%)$ on the basis of the label claim. At each level, three determinations were performed simultaneously and percentage recovery was calculated.

\section{Robustness}

Small Deliberate change in the method are made such as wavelength the determination of the Robustness was performed at $+1 \mathrm{~nm}$ and $-1 \mathrm{~nm}$ from the fixed wave length, \%RSD was calculated.

\section{Ruggedness}

The Ruggedness of both the methods was performed by changing analysts and instruments, $\%$ RSD were calculated.

\section{LOD \& LOQ}

LOD is defined as the lowest concentration of an analyte in sample that can be detected, not quantified. $\mathrm{LOD}=3.3 \mathrm{\sigma} / \mathrm{S}$

$\sigma=$ standard deviation of the response,

$\mathrm{S}=$ slope of calibration curve.

LOQ Is defined as the lowest concentration of an analyte in a sample that can be determined with acceptable precision and accuracy under the stated operational conditions of the method.

$$
\begin{aligned}
\mathrm{LOQ} & =10 \sigma / \mathrm{s} \\
\sigma & =\text { standard deviation of the response, } \\
\mathrm{S} & =\text { slope of calibration curve. }
\end{aligned}
$$

Analysis of formulation: Simultaneous Equation Method

For the analysis of formulation take the Marketed tablet formulation of DURART-R 450mg (400 mg of Darunavir + 50 mg of Ritonavir).

Weigh the 5 Tablets and powder them, Weigh accurately $10 \mathrm{mg}$ equivalent tablet powder in $10 \mathrm{ml}$ of volumetric flask dissolve it in methanol filtered and sonicated for $5 \mathrm{~min}$ which gives the stock solution of (1000ppm), from this take $0.1 \mathrm{ml}$ of the solution in to 10 $\mathrm{ml}$ volumetric flask and make up the volume up to $10 \mathrm{ml}$ with methanol (10ppm), this solution scanned.

Then, the Reported Amount of Darunavir and Ritonavir was calculated using simultaneous equation method given below:

$$
\begin{aligned}
& C_{X}=A_{2} a y_{1}-A_{1} a y_{2} / a x_{2} a y_{1}-a x_{1} a y_{2} \\
& C_{Y}=A_{1} a x_{2}-A_{2} a x 1 / a_{2} a y_{1}-a x_{1} a y_{2} \\
& A_{1}=\text { Absorbance of formulation at } 267 \mathrm{~nm} . \\
& A_{2}=\text { Absorbance of formulation at } 240 \mathrm{~nm} . \\
& a x_{1}=A b s o r p t i v i t y \text { of DRV at } 267 \mathrm{~nm} . \\
& a_{2}=A b s o r p t i v i t y \text { of DRV at } 240 \mathrm{~nm} . \\
& a y_{1}=\text { Absorptivity of RIT at } 267 \mathrm{~nm} . \\
& a_{2}=\text { Absorptivity of RIT at } 240 \mathrm{~nm} . \\
& C x=\text { Concentration of Darunavir. } \\
& C y=\text { Concentration of Ritonavir. }
\end{aligned}
$$

\section{Forced Degradation Studies}

Forced degradation studies are also known as stress testing. Forced degradation is a process that involves degradation of drug products and drug substances at conditions more severe than accelerated conditions and thus generates degradation products that can be studied to determine the stability of the molecule.

\section{Objective for forced Degradation Studies}

- To recognize the chemical properties of drug molecules.

- To elucidate the structure of degradation products.

- To resolve stability-related problems.

- To establish the stability of a drug substance in the formulation.

- To reveal the degradation mechanisms of the drug substance and drug product.

- To distinguish degradation products that is related to drug products.

ICH guidelines demonstrate certain degradation conditions like light, oxidation, dry heat, acidic, basic, hydrolysis etc. ICH Q1A, Q1B exemplify the forced degradation studies

ICH Q1A: stability testing of new drug substances and products

ICH Q1B: photo stability testing of new drug substances and products [19-21]. 


\section{Procedure}

\section{Acid Degradation}

From 10ppm of drug solution, taken $1 \mathrm{ml}$ of the $10 \mathrm{ppm}$ solution into $10 \mathrm{ml}$ volumetric flask $+1 \mathrm{ml}$ of $0.1 \mathrm{~N} \mathrm{HCl}$ kept for 24 hours. After 24 hours neutralize with $1 \mathrm{ml}$ of $0.1 \mathrm{~N} \mathrm{NaOH}$ Measured its absorbance at $251 \mathrm{~nm}$.

\section{Alkali Degradation}

From 10ppm of drug solution, taken $1 \mathrm{ml}$ of $10 \mathrm{ppm}$ solution into $10 \mathrm{ml}$ volumetric flask $+1 \mathrm{ml}$ of $0.1 \mathrm{~N} \mathrm{NaOH}$ Was kept for 24 hours. After 24 hours neutralize with $1 \mathrm{ml}$ of $0.1 \mathrm{~N} \mathrm{HCl}$ Measured its absorbance at $251 \mathrm{~nm}$.

\section{Photolytic Degradation}

$10 \mathrm{mg}$ of drug was exposed to UV light in UV chamber for 3 hrs by placing the drug in Petri dish. After $3 \mathrm{hrs}$ Sample was diluted to get concentration of 10 $\mu \mathrm{g} / \mathrm{ml}$ and absorbance was measured at $251 \mathrm{~nm}$.

\section{Thermal Degradation}

Drug was exposed to dry heat $40 \mathrm{C}$ in oven at for 3 hrs by placing the drugs in Petri dish. Weighed $10 \mathrm{mg}$ of drug and diluted to get a final concentration of $10 \mu \mathrm{g} / \mathrm{ml}$ Measure the absorbance at $251 \mathrm{~nm}$ and calculate the percentage of Degradation.

\section{RESULTS AND DISCUSSION}

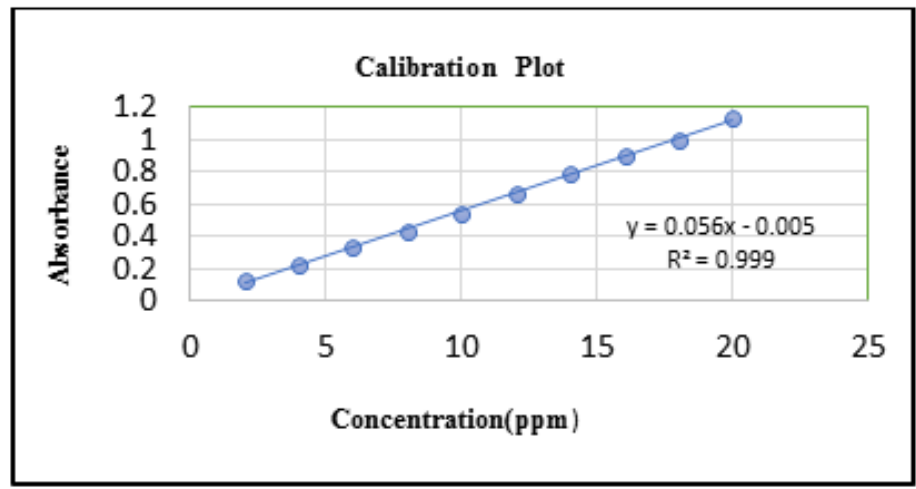

Fig-6: Calibration curve of Darunavir

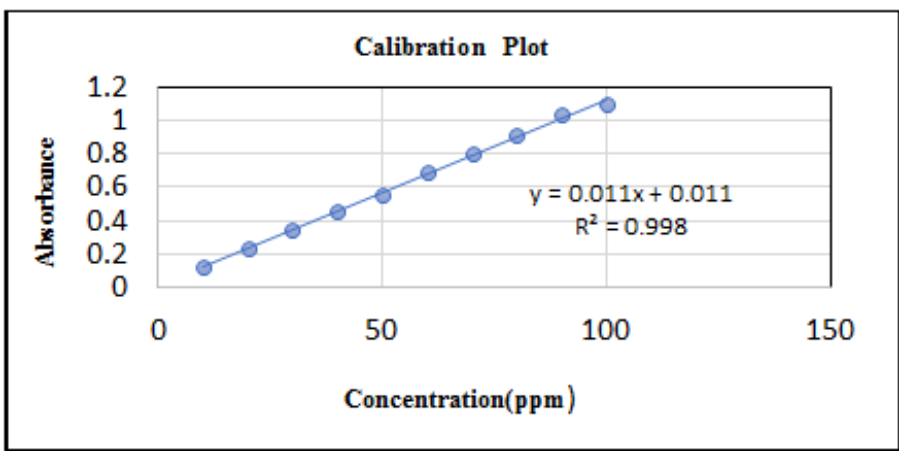

Fig-7: Calibration curve of Ritonavir

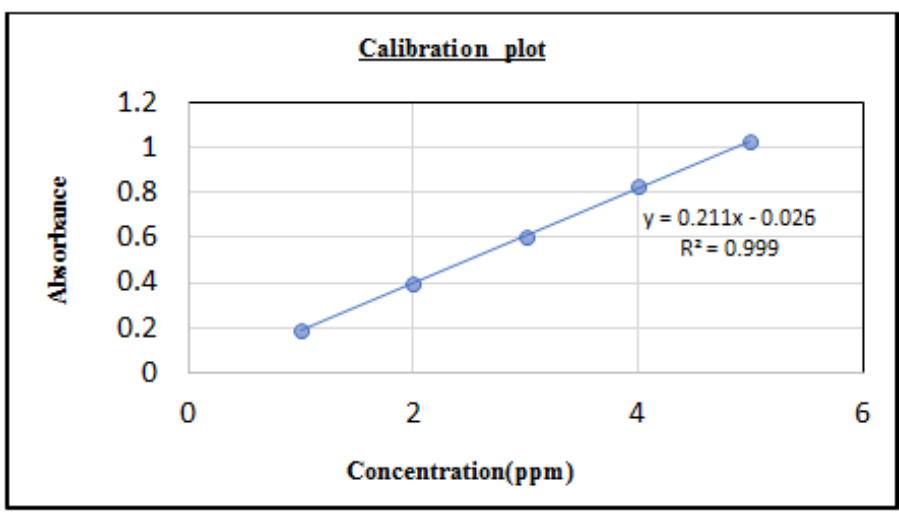

Fig-8: calibration plot of combined drugs 
Table-1: precision data

\begin{tabular}{|c|c|c|c|}
\hline S. No & $\begin{array}{c}\text { Darunavir (10ppm) } \\
\mathbf{2 6 7 n m}\end{array}$ & $\begin{array}{c}\text { Ritonavir (50ppm) } \\
\mathbf{2 4 0 n m}\end{array}$ & $\begin{array}{c}\text { Combined Drugs } \\
\mathbf{2 5 4 n m}(\mathbf{1 : 8})\end{array}$ \\
\hline 1 & 0.5147 & 0.5780 & 0.6076 \\
\hline 2 & 0.5145 & 0.5781 & 0.6075 \\
\hline 3 & 0.5140 & 0.5782 & 0.6074 \\
\hline 4 & 0.5135 & 0.5780 & 0.6075 \\
\hline 5 & 0.5145 & 0.5781 & 0.6074 \\
\hline 6 & 0.5157 & 0.5782 & 0.6073 \\
\hline Mean & 0.5144 & 0.5781 & 0.6074 \\
\hline SD & 0.0007386 & 0.0000894 & 0.000104 \\
\hline \%RSD & $0.143 \%$ & $0.0321 \%$ & $0.0172 \%$ \\
\hline
\end{tabular}

Table-2: Accuracy data of darunavir

\begin{tabular}{|c|c|c|c|c|}
\hline $\begin{array}{c}\% \\
\text { level }\end{array}$ & $\begin{array}{c}\text { Combined } \\
\text { concentration }\end{array}$ & $\begin{array}{c}\text { DRV } \\
\text { concentration }\end{array}$ & \% Recovery & $\begin{array}{c}\text { Mean\% } \\
\text { Recovery }\end{array}$ \\
\hline $50 \%$ & $1: 8$ & $2 \mathrm{ppm}$ & $99.1 \%$ & $99.3 \%$ \\
& & & $99.5 \%$ & \\
& $1: 8$ & $4 \mathrm{ppm}$ & $99.6 \%$ & \\
\hline $100 \%$ & & & $99.1 \%$ & $99.2 \%$ \\
& $1: 8$ & $6 \mathrm{ppm}$ & $100.1 \%$ & $100 \%$ \\
& & & $100.1 \%$ & \\
& & & $100 \%$ & \\
\hline
\end{tabular}

Table-3: Accuracy data of Ritonavir

\begin{tabular}{|c|c|c|c|c|}
\hline $\begin{array}{c}\% \\
\text { level }\end{array}$ & $\begin{array}{c}\text { Combined } \\
\text { concentration }\end{array}$ & $\begin{array}{c}\text { RIT } \\
\text { Concentration }\end{array}$ & \% Recovery & $\begin{array}{c}\text { \% Mean } \\
\text { Recovery }\end{array}$ \\
\hline $50 \%$ & $1: 8$ & $5 \mathrm{ppm}$ & $99.1 \%$ & $99.2 \%$ \\
& & & $99.2 \%$ & \\
& $1: 8$ & $10 \mathrm{ppm}$ & $99.3 \%$ & \\
\hline $100 \%$ & & & $99.5 \%$ & $99.3 \%$ \\
& $1: 8$ & $15 \mathrm{ppm}$ & $99.3 \%$ & \\
& & & $100 \%$ & \\
\hline $150 \%$ & & & $100 \%$ & \\
& & & & \\
& & & & \\
\end{tabular}

Table-4: Robustness data of Darunavir

\begin{tabular}{|c|c|c|}
\hline S. No & $\mathbf{2 6 6 n m}$ & $\mathbf{2 6 8 n m}$ \\
\hline 1 & 0.5152 & 0.5189 \\
\hline 2 & 0.5152 & 0.5188 \\
\hline 3 & 0.5150 & 0.5188 \\
\hline Mean & 0.5151 & 0.5188 \\
\hline SD & 0.000154 & 0.000057 \\
\hline \%RSD & $0.0298 \%$ & $0.0111 \%$ \\
\hline
\end{tabular}

Table-5: Robustness data of Ritonavir

\begin{tabular}{|c|c|c|}
\hline S.NO & 239nm & 241nm \\
\hline 1 & 0.5691 & 0.5792 \\
\hline 2 & 0.5653 & 0.5796 \\
\hline 3 & 0.5670 & 0.5802 \\
\hline Mean & 0.5671 & 0.5796 \\
\hline SD & 0.00190 & 0.000503 \\
\hline \%RSD & $0.711 \%$ & $0.1800 \%$ \\
\hline
\end{tabular}


Table-6: Robustness data of combined drugs

\begin{tabular}{|c|c|c|}
\hline S. No & $\mathbf{2 5 3 n m}$ & $\mathbf{2 5 5 n m}$ \\
\hline 1 & 0.5932 & 0.6154 \\
\hline 2 & 0.5936 & 0.6156 \\
\hline 3 & 0.5935 & 0.6154 \\
\hline Mean & 0.5934 & 0.6156 \\
\hline SD & 0.000208 & 0.0002 \\
\hline \%RSD & $0.0350 \%$ & $0.0324 \%$ \\
\hline
\end{tabular}

Table-7: Ruggedness data of darunavir

\begin{tabular}{|c|c|c|}
\hline \multirow{2}{*}{ S. No } & \multicolumn{2}{|c|}{ Absorbance (Abs) } \\
\cline { 2 - 3 } & Analyst-1 & Analyst-2 \\
\hline 1 & 0.5086 & 0.5069 \\
\hline 2 & 0.5089 & 0.5073 \\
\hline 3 & 0.5080 & 0.5078 \\
\hline Mean & 0.5085 & 0.5073 \\
\hline SD & 0.000458 & 0.000450 \\
\hline \%RSD & $0.09 \%$ & $0.0887 \%$ \\
\hline
\end{tabular}

Table-8: Ruggedness data of Ritonavir

\begin{tabular}{|c|c|c|}
\hline \multirow{2}{*}{ S. No } & \multicolumn{2}{|c|}{ Absorbance (Abs) } \\
\cline { 2 - 3 } & Analyst-1 & Analyst-2 \\
\hline 1 & 0.5691 & 0.5792 \\
\hline 2 & 0.5653 & 0.5796 \\
\hline 3 & 0.5673 & 0.5802 \\
\hline Mean & 0.5672 & 0.5796 \\
\hline SD & 0.000190 & 0.0005033 \\
\hline \%RSD & $0.0334 \%$ & $0.0868 \%$ \\
\hline
\end{tabular}

Table-9: Ruggedness data of combined drugs

\begin{tabular}{|c|c|c|}
\hline \multirow{2}{*}{ S. No } & \multicolumn{2}{|c|}{ Absorbance (Abs) } \\
\cline { 2 - 3 } & Analyst-1 & Analyst-2 \\
\hline 1 & 0.6132 & 0.6025 \\
\hline 2 & 0.6131 & 0.6025 \\
\hline 3 & 0.6132 & 0.6024 \\
\hline 4 & 0.6133 & 0.6023 \\
\hline 5 & 0.6132 & 0.6024 \\
\hline 6 & 0.6131 & 0.6024 \\
\hline Mean & 0.6131 & 0.6025 \\
\hline SD & 0.0000752 & 0.0000816 \\
\hline \%RSD & $0.0122 \%$ & $0.0135 \%$ \\
\hline
\end{tabular}

Table-10: LOD\&LOQ data of Darunavir and Ritonavir

\begin{tabular}{|c|c|c|}
\hline & LOD & LOQ \\
\hline DRV & $0.043 \mu \mathrm{g} / \mathrm{ml}$ & $0.132 \mu \mathrm{g} / \mathrm{ml}$ \\
\hline RIT & $0.024 \mu \mathrm{g} / \mathrm{ml}$ & $0.078 \mu \mathrm{g} / \mathrm{ml}$ \\
\hline
\end{tabular}

Table-10: Analysis of formulation by simultaneous method

\begin{tabular}{|c|c|}
\hline Drugs name & Concentrations \\
\hline Darunavir $\mathrm{C}_{\mathrm{x}}$ & $8.8 \mu \mathrm{g} / \mathrm{ml}$ \\
\hline Ritonavir $\mathrm{C}_{\mathrm{y}}$ & $1.1 \mu \mathrm{g} / \mathrm{ml}$ \\
\hline
\end{tabular}


Table-11: stress studies

\begin{tabular}{|c|c|c|}
\hline Type of Degradation & Darunavir & Ritonavir \\
\hline Acid Degradation $(0.1 \mathrm{~N} \mathrm{HCL})$ & $19.1 \%$ & $15 \%$ \\
\hline Alkali Degradation $(0.1 \mathrm{~N} \mathrm{NaOH})$ & $19 \%$ & $17 \%$ \\
\hline $\begin{array}{c}\text { Photolytic Degradation } \\
\text { (UV Chamber) }\end{array}$ & $17 \%$ & $18.5 \%$ \\
\hline $\begin{array}{c}\text { Peroxide Degradation } \\
\left(3 \% \mathrm{H}_{2} \mathrm{O}_{2}\right)\end{array}$ & $19.6 \%$ & $17.8 \%$ \\
\hline $\begin{array}{c}\text { Thermal Degradation } \\
(\text { Hot air Oven-40 } \mathrm{c})\end{array}$ & $15 \%$ & $16.4 \%$ \\
\hline
\end{tabular}

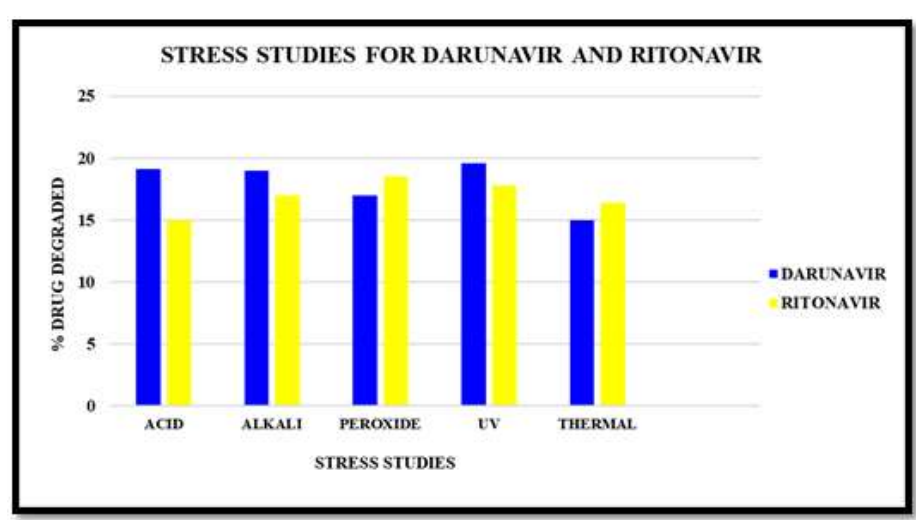

Fig-9: Stress studies of Darunavir and Ritonavir

\section{CONCLUSION}

The developed UV spectrophotometric method is simple, precise, accurate, linear, and reproducible for the estimation of Darunavir and Ritonavir in combined dosage form without any interference from the excipients. It can be successfully applied for the routine analysis of both the drugs in pharmaceutical dosage form.

\section{ACKNOWLEDGMENT}

We are thankful that RBVRR Women's College of Pharmacy has provided us the opportunity to write this research article.

\section{REFERENCES}

1. Mrinalini damle and ajinkya deosthali Uvspectrophotometric absorbance correction method and absorbance ratio method for the simultaneous estimation of ritonavir and darunavir ethanolate world journal of pharmacy and pharmaceutical sciences. 2016; 5(8): 1179-1187

2. Gholve Sachin B, Asware Baburao S, Kadam Shrihari C, Bhusnure Omprakash G, Thonte Sanjay S. Development and validation of a simple UV spectrophotometric method for the determination of Darunavir ethanolate both in bulk and marketed dosage formulations.

3. Seetaramaiah K, Smith AA, Ramyateja K, Alagumanivasagam G, Manavalan R. Spectrophotometric determination of ritonavir in bulk and pharmaceutical formulation. Scientific Reviews \& Chemical Communications. 2012;2:16.
4. Redasani VK, Patel PR, Marathe DY, Chaudhari SR, Shirkhedkar AA, Surana SJ. A review on derivative Uv-spectrophotometry analysis of drugs in pharmaceutical formulations and biological samples review. Journal of the Chilean Chemical Society. 2018;63(3):4126-34.

5. Ghante MR, Shelar RS, Sawant SD, Kadam MM. Development and validation of UV spectrophotometric method for estimation of darunavir ethanolate in bulk and tablet dosage form. Int. J. Pharm. Pharm. Sci. 2014;6:240-.

6. Corrêa JC, Serra CH, Salgado HR. Stability study of darunavir ethanolate tablets applying a new stability-indicating HPLC method. Chromatography Research International. 2013;2013.

7. Satyanarayana L, Naidu SV, Rao MN, Kumar A, Suresh K. The Estimation of Darunavir in Tablet dosage form by RP-HPLC. Asian Journal of Research in Pharmaceutical Science. 2011;1(3):746.

8. Patel BN, Suhagia BN. Simultaneous determination and validation of Darunavir ethanolate and Ritonavir in binary mixture by liquid chromatography. Int. J Pharm Tech Res. 2012;4(4):1450-6.

9. Karthika A, Rama K, Chenthilnathan A. RP-HPLC method development and validation for quantification of darunavir ethanolate in tablet dosage form. Der Pharmacia Lettre. 2016;8(5):2916.

10. Curran A, Gutirerrez M, Deig E, Mateo G, Lopez RM, Imaz A, Crespo M, Ocana I, Domingo P, Ribera E. Efficacy, safety and pharmacokinetics of 
$900 / 100 \mathrm{mg}$ of darunavir/ritonavir once daily in treatment-experienced patients. Journal of antimicrobial chemotherapy. 2010 Oct 1;65(10):2195-203.

11. Garcia SP, Tunica DG, Serra MB. Development and assessment of a method for the determination of darunavir in plasma by $1 \mathrm{C}-\mathrm{MS} / \mathrm{MS}$. Desarrollo y validación de un método para la determinación de darunavir en plasma mediante 1C-MS/MS.) Rev lab Clin. 2011;4:127-33.

12. Else L, Watson V, Tjia J, Hughes A, Siccardi M, Khoo S, Back D. Validation of a rapid and sensitive high-performance liquid chromatography-tandem mass spectrometry (HPLC-MS/MS) assay for the simultaneous determination of existing and new antiretroviral compounds. Journal of Chromatography B. 2010 Jun 1;878(19):1455-65.

13. Atole DM, RAJPUT HH. Ultraviolet spectroscopy and its pharmaceutical applications-a brief review. Asian J Pharm Clin Res. 2018;11(2):59-66.

14. Shah RS, Shah RR, Pawar RB, Gayakar PP. International Journal of Institutional Pharmacy and Life Sciences. International Journal of Institutional pharmacy and life sciences.;5:490-505.

15. Choudhary A. The principle of Ultra Violet (UV) Spectrophotometer. Medium. com. 2017.

16. Curran A, Gutirerrez M, Deig E, Mateo G, Lopez RM, Imaz A, Crespo M, Ocana I, Domingo P, Ribera E. Efficacy, safety and pharmacokinetics of
$900 / 100 \mathrm{mg}$ of darunavir/ritonavir once daily in treatment-experienced patients. Journal of antimicrobial chemotherapy. 2010 Oct 1;65(10):2195-203.

17. Garcia SP, Tunica DG, Serra MB. Development and assessment of a method for the determination of darunavir in plasma by $1 \mathrm{C}-\mathrm{MS} / \mathrm{MS}$. Desarrollo y validación de un método para la determinación de darunavir en plasma mediante 1C-MS/MS.) Rev lab Clin. 2011;4:127-33.

18. Else L, Watson V, Tjia J, Hughes A, Siccardi M, Khoo S, Back D. Validation of a rapid and sensitive high-performance liquid chromatography-tandem mass spectrometry (HPLC-MS/MS) assay for the simultaneous determination of existing and new antiretroviral compounds. Journal of Chromatography B. 2010 Jun 1;878(19):1455-65.

19. Blessy MR, Patel RD, Prajapati PN, Agrawal YK. Development of forced degradation and stability indicating studies of drugs - A review. Journal of pharmaceutical analysis. 2014 Jun 1;4(3):159-65.

20. Chan CP. Forced degradation studies: current trends and future perspectives for protein-based therapeutics. Expert Review of Proteomics. 2016 Jul 2;13(7):651-8.

21. Iram F, Iram H, Iqbal AZ, Husain A. Forced degradation studies. J Anal Pharm Res. 2016;3(6):00073. 